\title{
A farewell from the Editor
}

\section{Mariano J. AZNAR*}

Eight years ago, I had the privilege of being elected Editor-in-Chief of the Spanish Yearbook of International Law (SYbIL). This was just after the General Assembly of the 'Asociación Española de Profesores de Derecho Internacional y Relaciones Internacioanles' (AEPDIRI), held in September 20I3, which renovated the Editorial Council of the SYbIL, but also endorsed some proposals for this new epoch of the Yearbook: to change its structure, to move it to the web with total free access, and to offer its pages to any scholar willing to work and publish with us.

Since then, I have been accompanied in this task by several colleagues and good friends whose efforts in this editorial endeavour have been indispensable: Elena Conde, Noe Cornago, Federico Garau, Iván Heredia, Guillermo Palao, Ángel Rodrigo, Ana Salinas, Ángel Sánchez-Legido and Marina Vargas. During the 2013-202o period, professors Rodrigo and Sánchez-Legido have acted as Assistant Editors. Some other people have also helped with particular tasks, entrusted by the Editorial Board or myself, such as our dear colleagues Marta Abegón, Ana María Maestro and Beatriz Vazquez; or three graduate students from Universitat Jaume I -Lidón Cruselles, Hanan Laghrich and Santiago Bernabé - who assisted me. We have also counted with the help of Kari Friedenson - translating and revising English texts — and dozens of peer-reviewers who made a silent but unvaluable task of scientifically crediting the SYbIL among reliable publications in International Law, today included in several scientific quality indexes.

$*$

The publication of several Agorae and Fora - echoing different scientific activities of our AEPDIRI's colleagues - gave us the additional opportunity to be assisted by Montse Abad, Laura Carballo, Yolanda Gamarra, Marzia Scopelliti, Esperanza Orihuela, José M. Sobrino, Carlos Jiménez, Xavier Pons, Joana Abrisketa and Enrique Martinez, all of them supervising these symposiums or colloquia, which discussed subjects such as the extraterritorial application of EU Law, the European arctic policy, the secession and selfdetermination in current International Law, EU asylum policies or the consequences of walls in International Law. Along with these activities, the SYbIL organized and published the result of other scientific activities focusing on Spanish practice on the universal

\footnotetext{
* Professor of Public International Law, Universitat Jaume I. Email: maznar@uji.es.
} 
jurisdiction, the use of force, its UN and EU membership, Spain's practice as UNCLOS state party, our Nation's practice regarding human rights' bodies or the domestic judicial decisions on the secession's attempt in Catalonia.

SYbIL has also nested several analyses of Spanish practice in more than a dozen of other contributions published, along with the review of almost 40 books published by Spanish authors; and, since its volume 22, the listing of the English abstracts of doctrinal contributions published by our sister journals in AEPDIRI: the Revista Española de Derecho Internacional and the Revista Electrónica de Estudios Internacionales, whose editors-in-chief kindly helped us during these years as well.

In these seven volumes since 2013 we have published 40 doctrinal essays, plus two special contributions by Carmen Martínez and Antonio Remiro, trying to discuss an array of theoretical studies, contemporary questions, fresh events and their legal consequences, but also classics approaches to core questions of Public and Private International Law and International Relations. The later were included in our "Classics' corner" section, opening each volume, and reproducing different papers —originally published in Spanish and now translated into English_ written by Spanish masters of our disciplines years ago but still seminal. Hence, we welcome contributions by Antonio Truyol, Adolfo Miaja, Mariano Aguilar, Enrique Pecourt, Roberto Mesa, Gil Carlos Rodríguez Iglesias and Alejandro Rodríguez Carrión. To this impressive club of big names, our volume 20 devoted that Corner to the greatest hero of Spanish literacy: Miguel de Cervantes, and the place of International law and diplomacy in his writings.

To sum up, 206 contributions in seven volumes, which complete the previous collection published in volumes I-I7 with Brill, under the direction of my predecessors. Amongst them, I would like to thanks Carlos Jiménez-Piernas; as well as to Paz Andrés, Araceli Mangas and Jorge Cardona, who gave me their advices on how to smoothly perform the always complex task of editing a Yearbook. Last but not least, José M. Sobrino, Carlos Esplugues and Caterina García -AEPDIRI presidents during my term- who enthusiastically supported our job at SYbIL also deserve their mention here.

Volume 24-my last volume - is published in 2020, a terrible year. We all lost beloved people, including relatives, friends, and colleagues. The COVIDig pandemic has been a worldwide disaster which has transformed our way of life. It has also stressed some rules and international structures we were convinced they would provide early warning and rapid response to the effects of the lethal virus. Our developed countries have been beat but, as usual, undeveloped countries have received less attention and help than needed.

Besides the pandemic, unresolved migrations, the loss of human lives at sea, devastating endless wars, uncontrolled criminal networks trafficking with humans, arms, drugs or cultural objects, sea-level rising, oceans' acidification and other climate-change effects, or the vanishing into "trans-national" what was previously supervised as "international" are 
some of many concerns we have witnessed during these last years. Leadership in the bigthree has not been very helpful, and Brexit has kidnapped the big-fourth (the EU) too many times, instead of being centred on what really matters.

Some of these questions have had a particularly effect in Spain: the pandemic is beating us too hard, too long and too irremediably; uncontrolled migration has increased, being used by our southern neighbour as a political tool; and, still in our south, Spain's shameful and illegal abandonment of the Sahrawis — do not forget: Spanish citizens in $1975-$ ease the path to end their legitimate right to self-determination, a path paved by universal and regional inaction and by the well-known hypocrisy of two western nuclear powers. One of them, at the end of 2020, crossed a red line of International Law when declaring Moroccan sovereignty over the Sahara.

However, I don't like to end this farewell with sad comments only. I truly believe on the resilience of our planet if we react as soon as possible. I am confident on our colleagues fighting against the virus in their laboratories, using their best knowledge. I also do trust in "Politics" — capitalised — against populisms and "strong leaders", against fake-news and big corporations' market tyranny, and against disenchantment with democracy and the state-of-law, all of them terrible viruses of our current societies. As internationalists, we are not policy- or law-makers, but we do have the responsibility to educate them within the language and the purposes of International Law -particularly defending multilateralism and human rights. We have to be willing and able to criticize or applaud those decision-makers. I am sure that the Spanish Yearbook of International Law will continue to welcome these scientific criticisms and applauses, as it always did.

Mariano J. Aznar on the last day of 2020 